Prace Historyczno-Archiwalne t. XXXII

ISSN: 1231-3335

\title{
SPRAWOZDANIA
}

\section{„Już setki razy pisałem do Was..." \\ - wystawa w Archiwum Państwowym w Rzeszowie w ramach Obchodów Międzynarodowego Dnia Pamięci o Ofiarach Holocaustu na Podkarpaciu}

W 2020 roku obchody Międzynarodowego Dnia Pamięci o Ofiarach Holocaustu odbyły się na Podkarpaciu w ponad 30 miejscowościach. Zaczęły się 2 stycznia i trwały do 22 lutego 2020 r. Podczas obchodów odbywały się modlitwy dla uczczenia pamięci pomordowanych Żydów, prelekcje i wykłady historyków, sesje naukowe poświęcone Zagładzie, stosunkom polsko-żydowskim i kulturze żydowskiej, pokazy filmów o tematyce związanej z Holocaustem, wystawy okolicznościowe, koncerty, prezentacje wspomnień ocalonych z Zagłady oraz spotkania ze świadkami historii.

Archiwum Państwowe w Rzeszowie chcąc uhonorować Dni Pamięci o Ofiarach Holocaustu, zorganizowało wystawę listów do rodzin, które pozostały w Rzeszowie i okolicy, lub rodzin na dalekiej obczyźnie, a które nigdy nie dotarły do adresatów. Otwarcie wystawy zatytułowanej „Już setki razy pisałem do Was...” miało miejsce 28 stycznia 2020 roku w siedzibie Archiwum.

Listy pełne emocji, niepokoju, tęsknoty, rozpaczy, pisane piękną kaligrafią nie tylko w języku polskim, ale i hebrajskim, i rosyjskim w większości pozostały bez odpowiedzi, o czym świadczą słowa: Kochany tatusiu - na wszystkie moje listy..., albo: ... Na niezliczonq ilość pism, które do Was pisałem...

Korespondencję zaprezentowano w grupach o różnym nasyceniu emocjonalnym, m.in: „Ktokolwiek...”, „Miłość”, „Tęsknota”. Listów zgromadzono około 2 tysięcy. Nigdy wcześniej nie były one pokazywane ani publikowane. Organizatorzy wystawy mieli dylemat, bo list to przecież coś bardzo osobistego, ale na wielu z kartek pocztowych znaleźli zdanie: ktokolwiek przeczyta tę kartkę... Na otwarciu wystawy czytali je między innymi rzeszowscy licealiści.

Przestrzeń pomiędzy gablotami wypełniła wzruszająca ekspozycja symbolizującą nie tylko „drogę listu” począwszy od jego napisania na dalekiej obczyźnie, ale także uczucia i emocje, jakie temu towarzyszyły. Przekaz dopełniły zgromadzone rekwizyty, jak kałamarz, walizki, droga wysypana piaskiem i kamieniami z drutem kolczastym, zakończona mnóstwem rozsypanych listów i wymowną figurą splecionych dłoni - symbolizujących tęsknotę, rozłąkę, miłość - często zagubioną, przerwaną.

Dla niektórych z zaproszonych gości otwarcie wystawy było nie tylko żywą lekcją historii, ale również dotykaniem historii własnej rodziny. Pan Yacov Blasbalg przyjechał do Rzeszowa z Tel Avivu w poszukiwaniu swoich korzeni i podczas otwar- 
cia wystawy ze wzruszeniem opowiadał o odnalezionych informacjach dotyczących 50 członków swojej rodziny, z której przeżył tylko jego ojciec.

Odwiedzający wystawę podkreślali, że dziś nie sposób wyobrazić sobie tamte czasy, jednakże biorąc do ręki zachowane listy, uświadamiali sobie, czym był Holocaust, wojna i jakie emocje towarzyszyły wtedy korespondencji. Niesamowitym przekazem okazały się spostrzeżenia, że działy się piękne rzeczy w nieludzkich warunkach, że w ekstremalnych sytuacjach, gdy szalała nienawiść, można było kochać i być solidarnym człowiekiem.

Prezentowane na wystawie listy to żywa pamięć, która powinna być zachowywana dla kolejnych pokoleń, która uczy szacunku i poświęcenia. Lekcja, która zostawia niezatarty ślad.

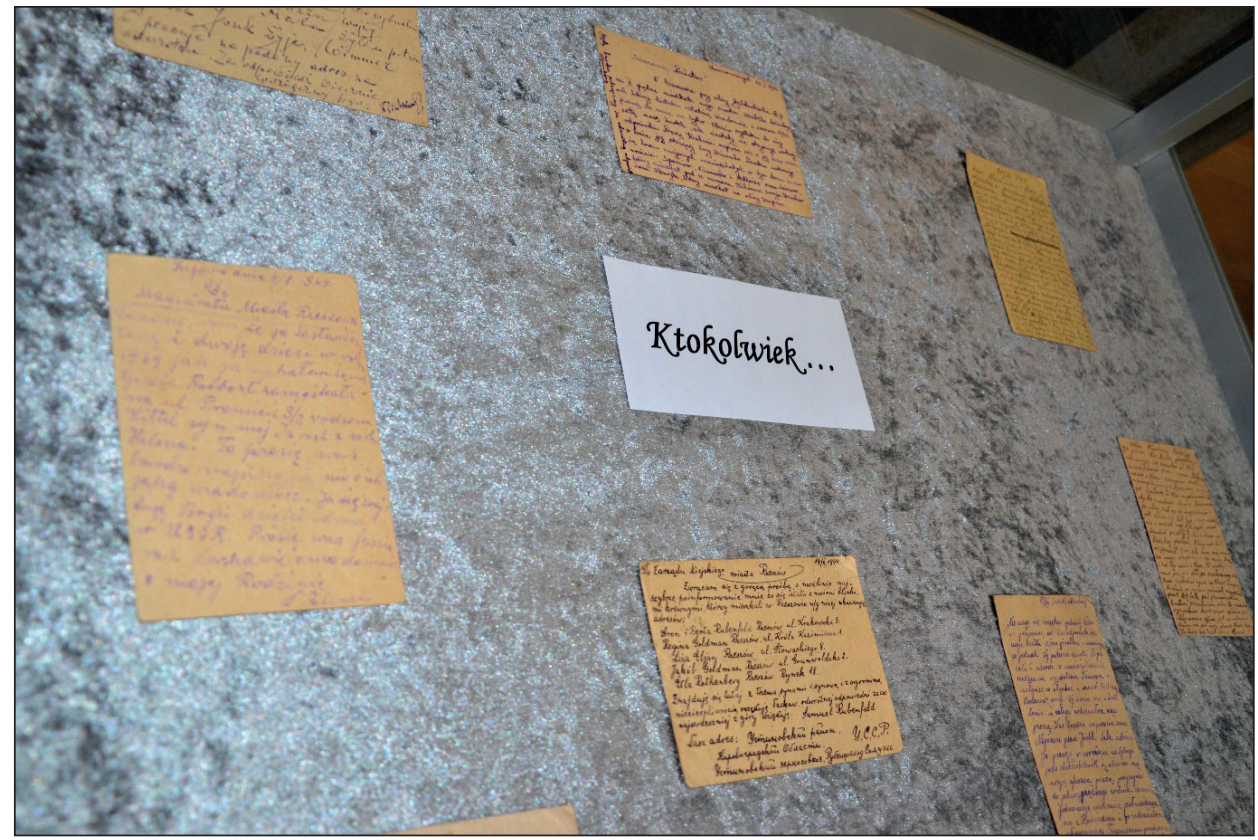

Fot. Maciej Zdun 


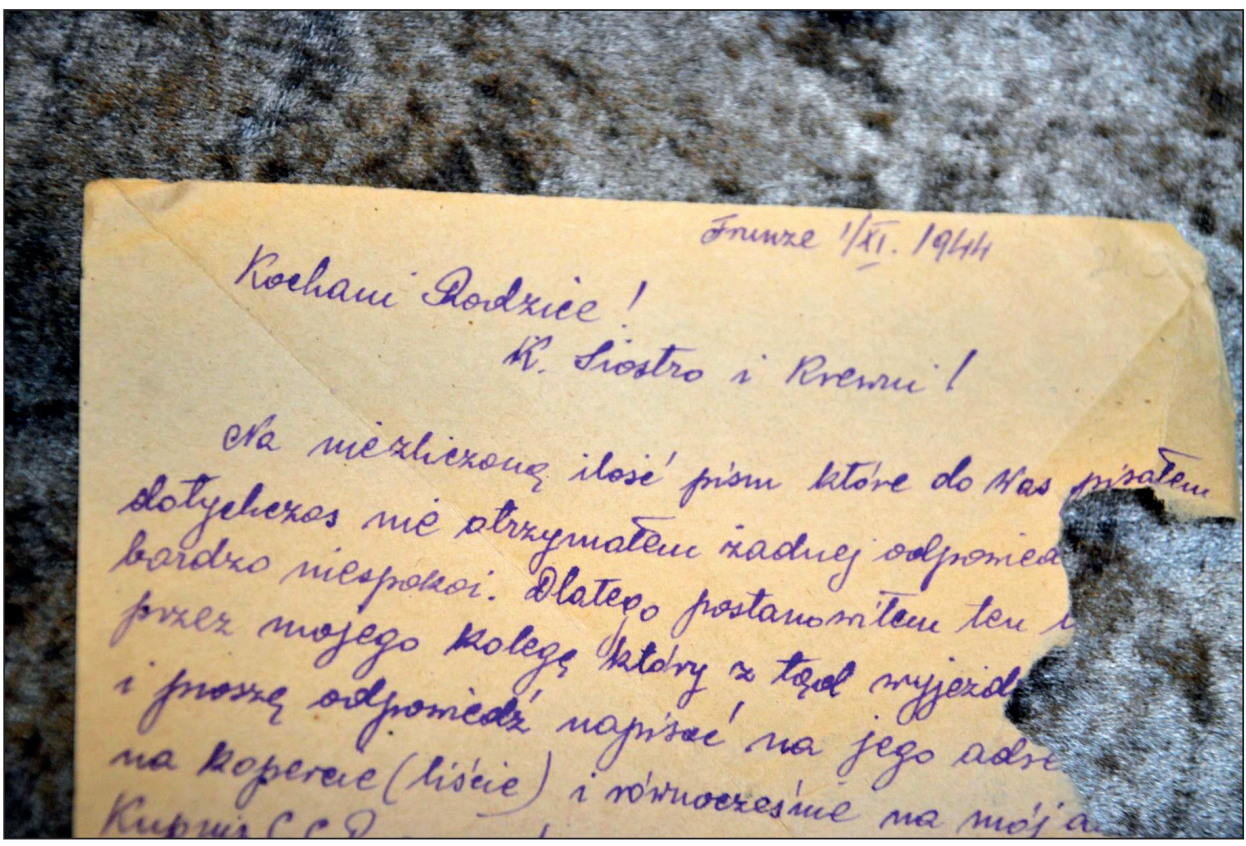

Fot. Maciej Zdun

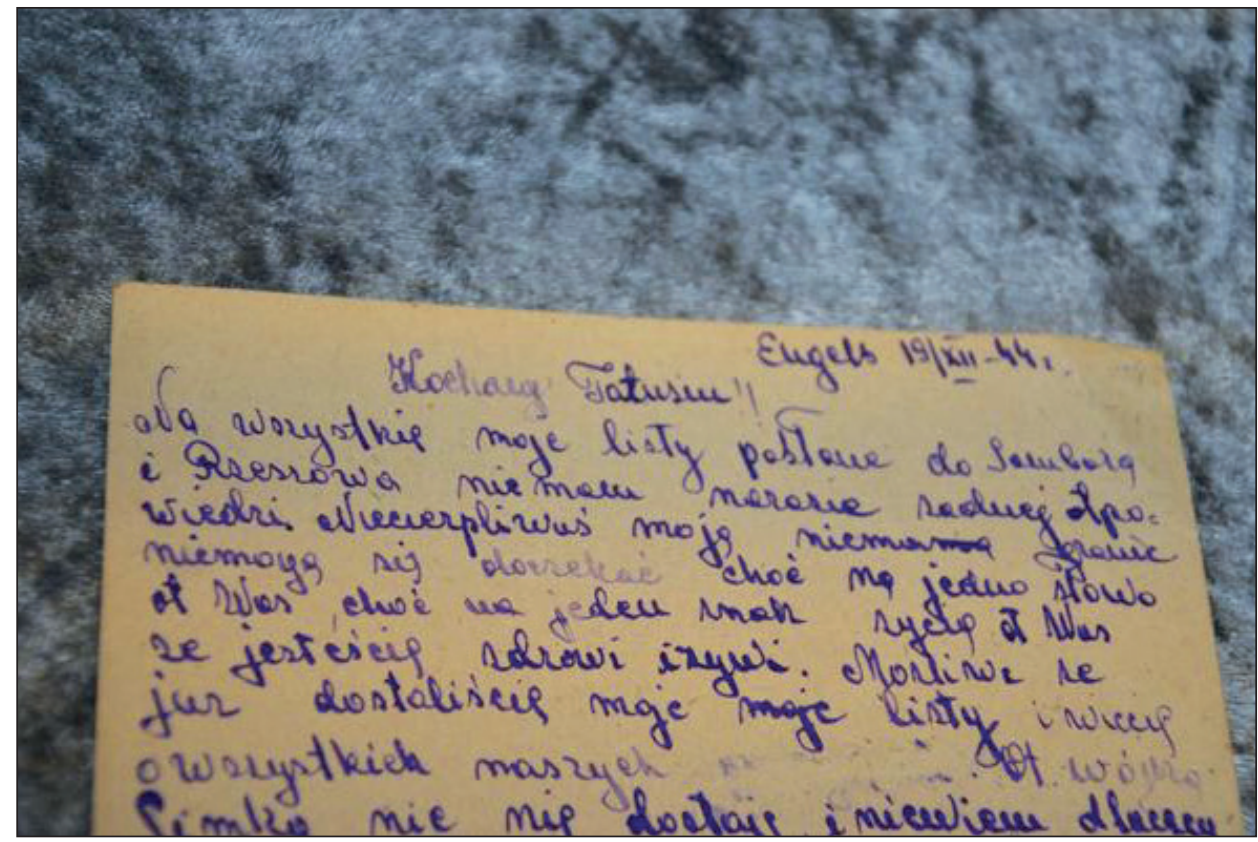

Fot. Maciej Zdun 


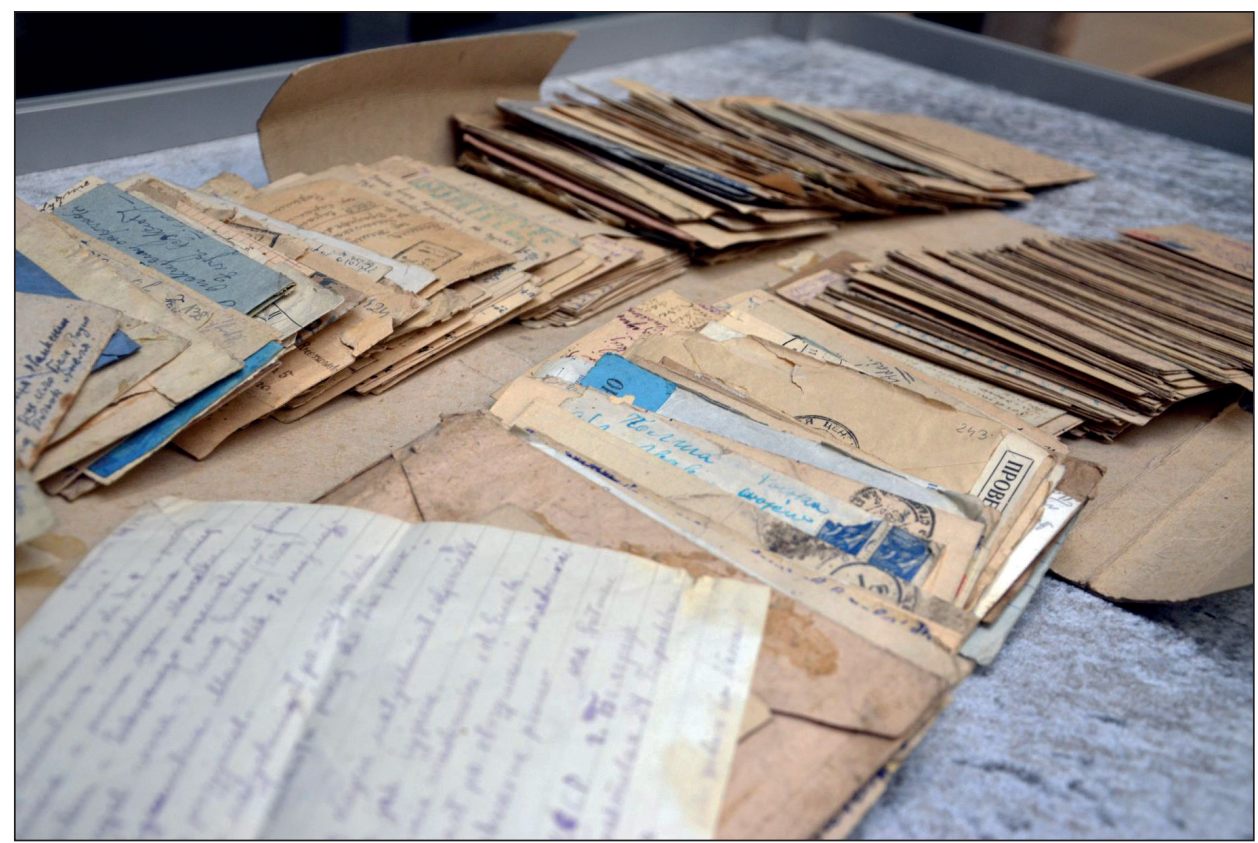

Fot. Maciej Zdun

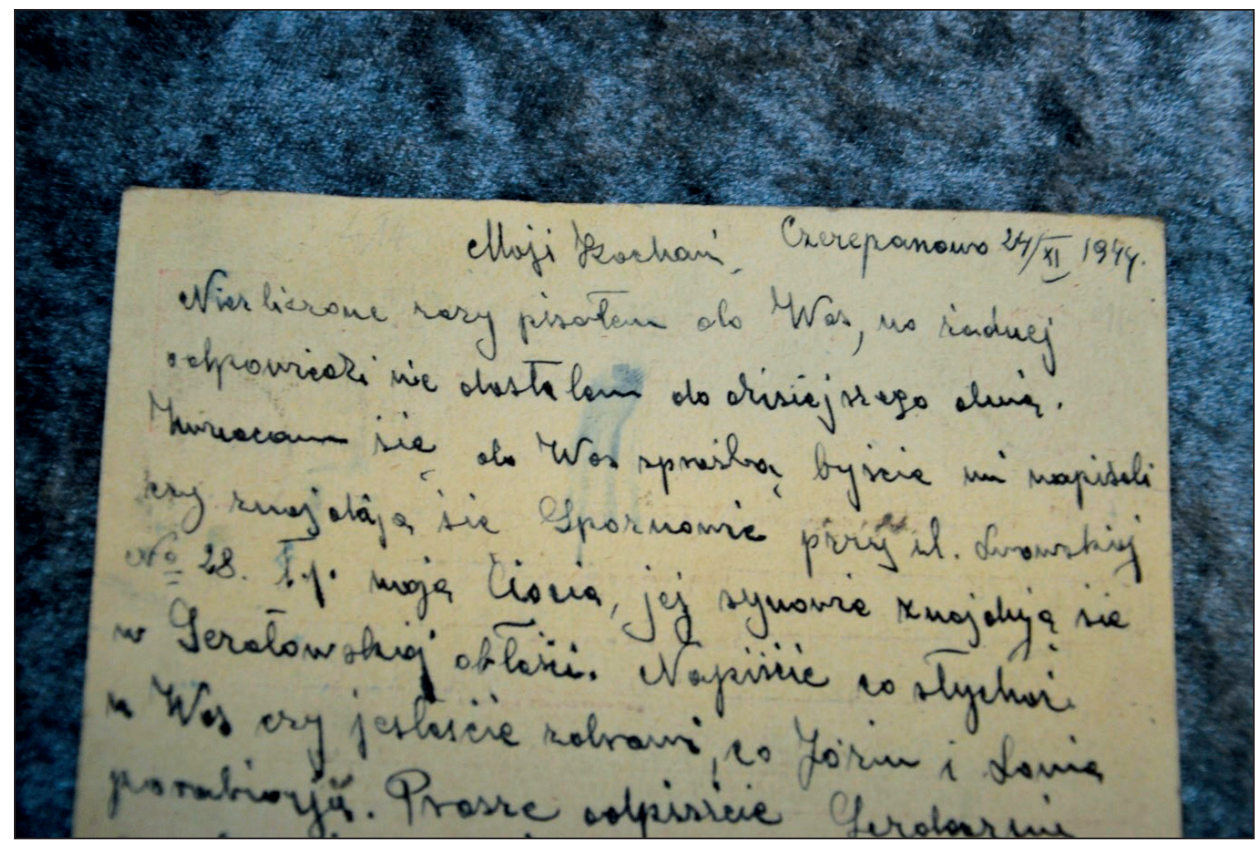

Fot. Maciej Zdun 


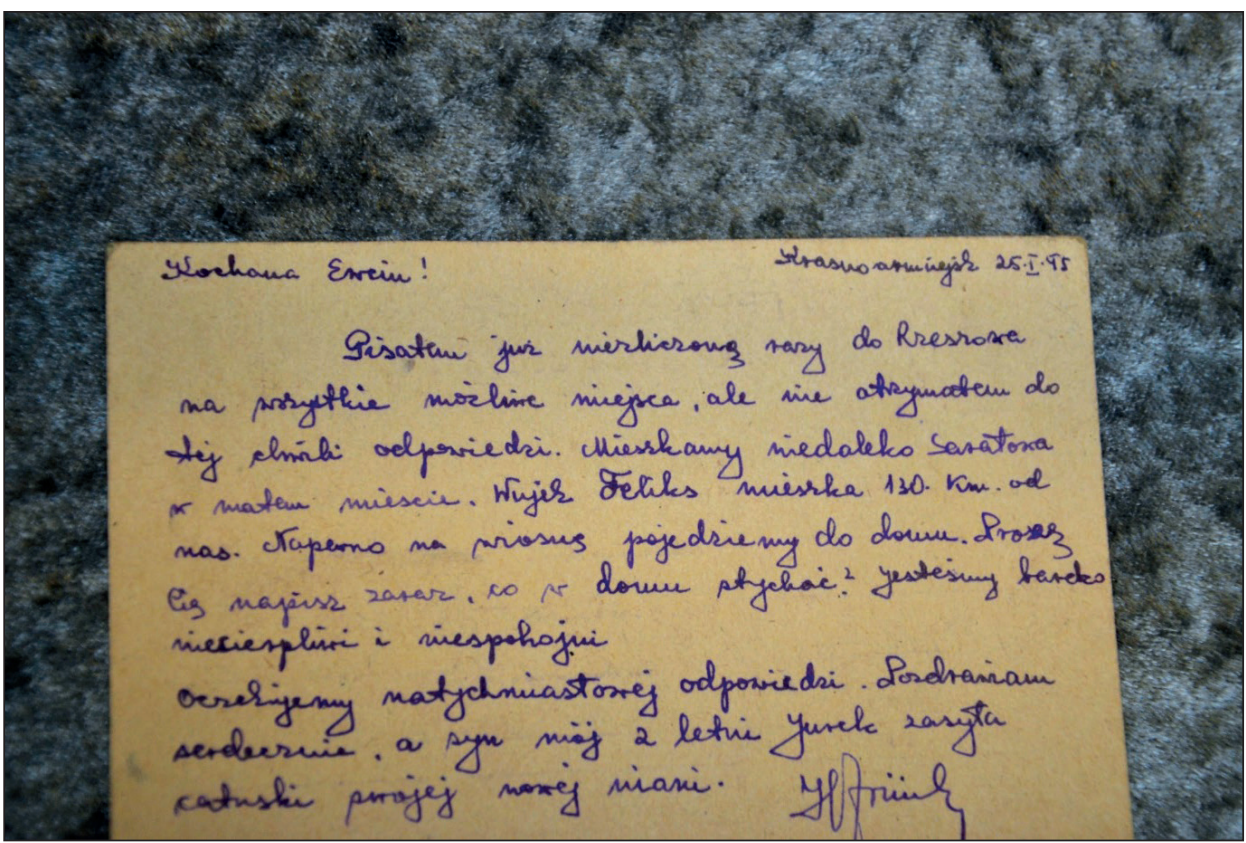

Fot. Maciej Zdun

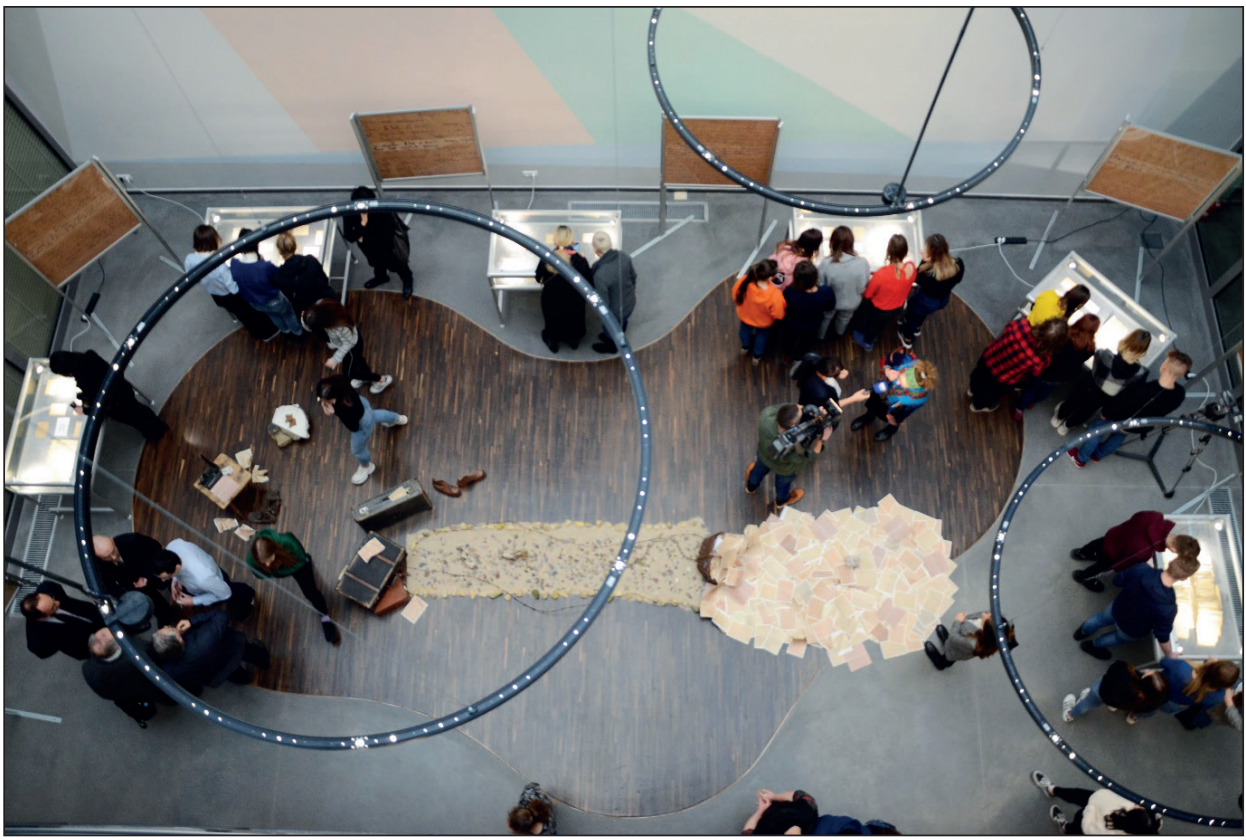

Fot. Maciej Zdun 


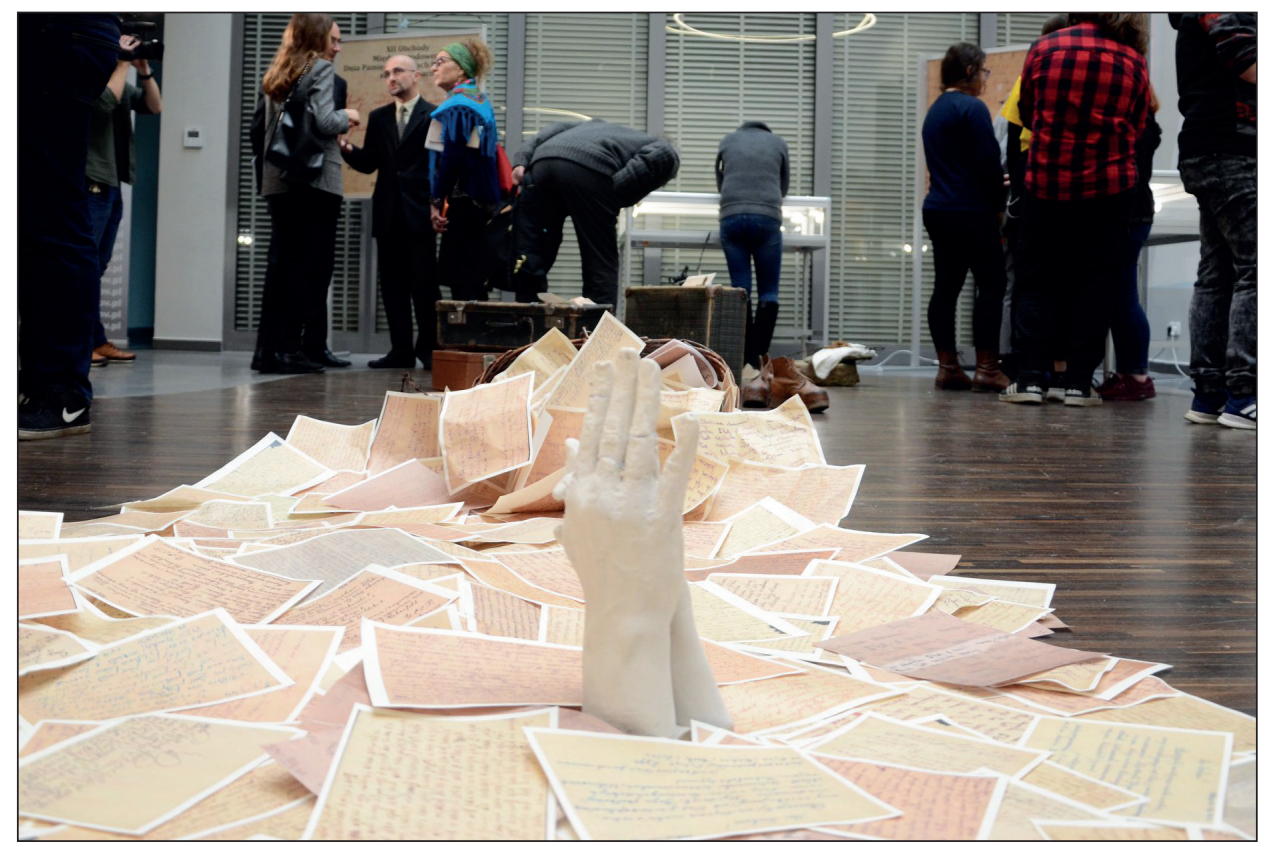

Fot. Maciej Zdun

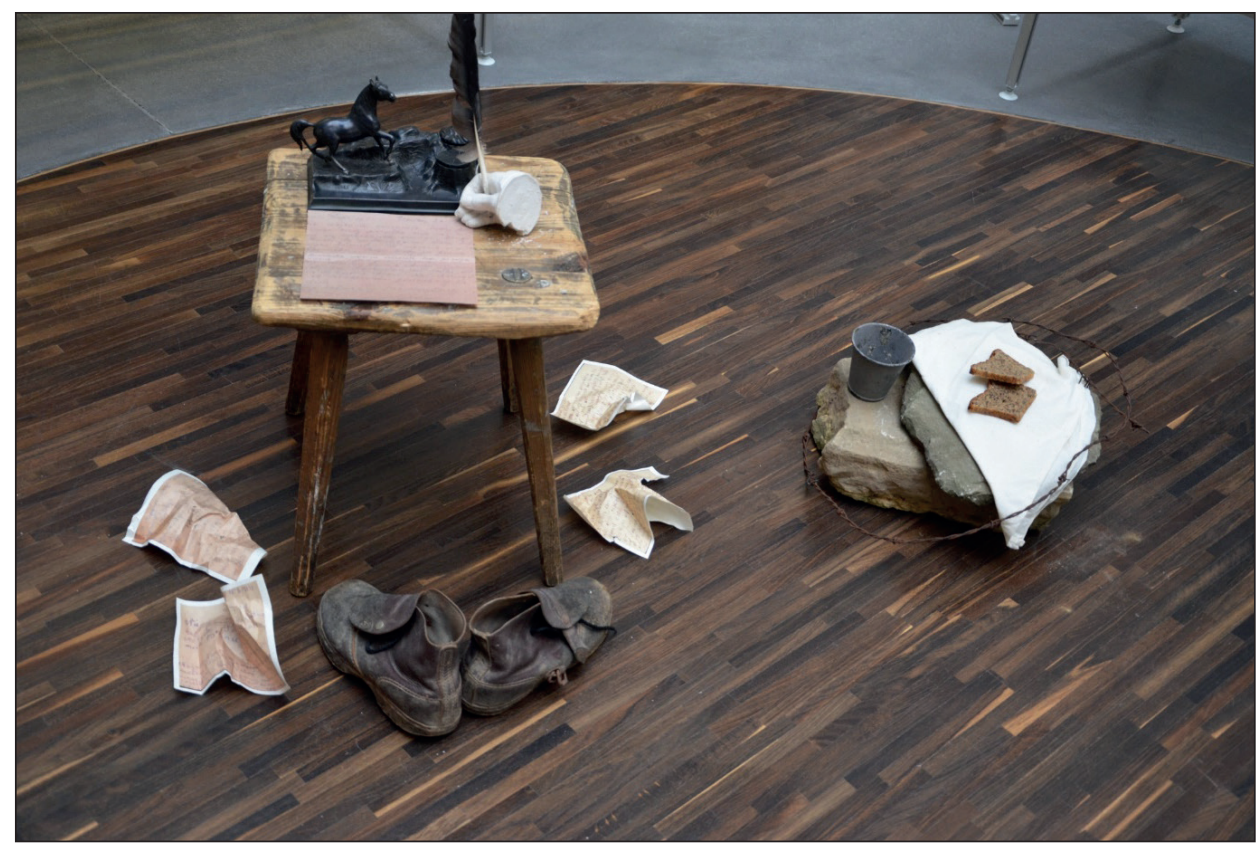

Fot. Maciej Zdun 


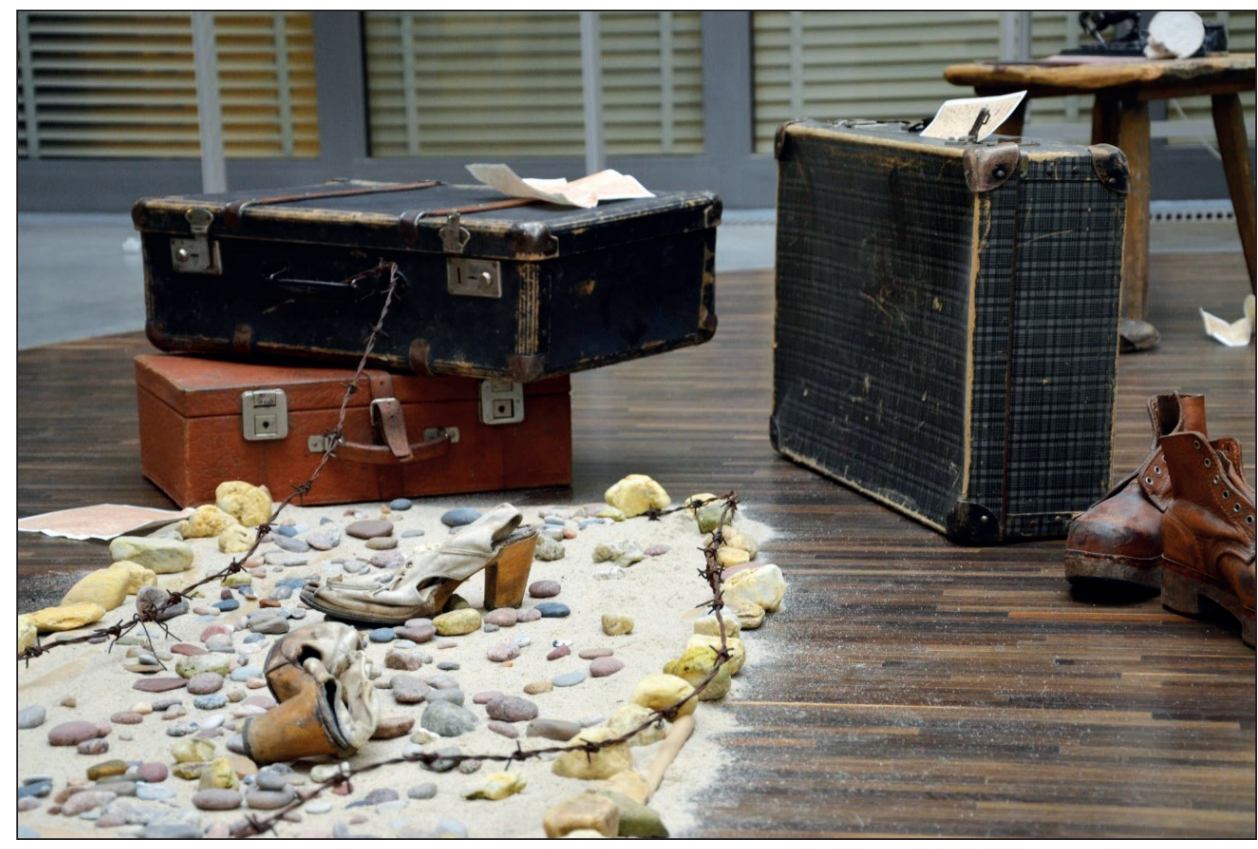

Fot. Maciej Zdun

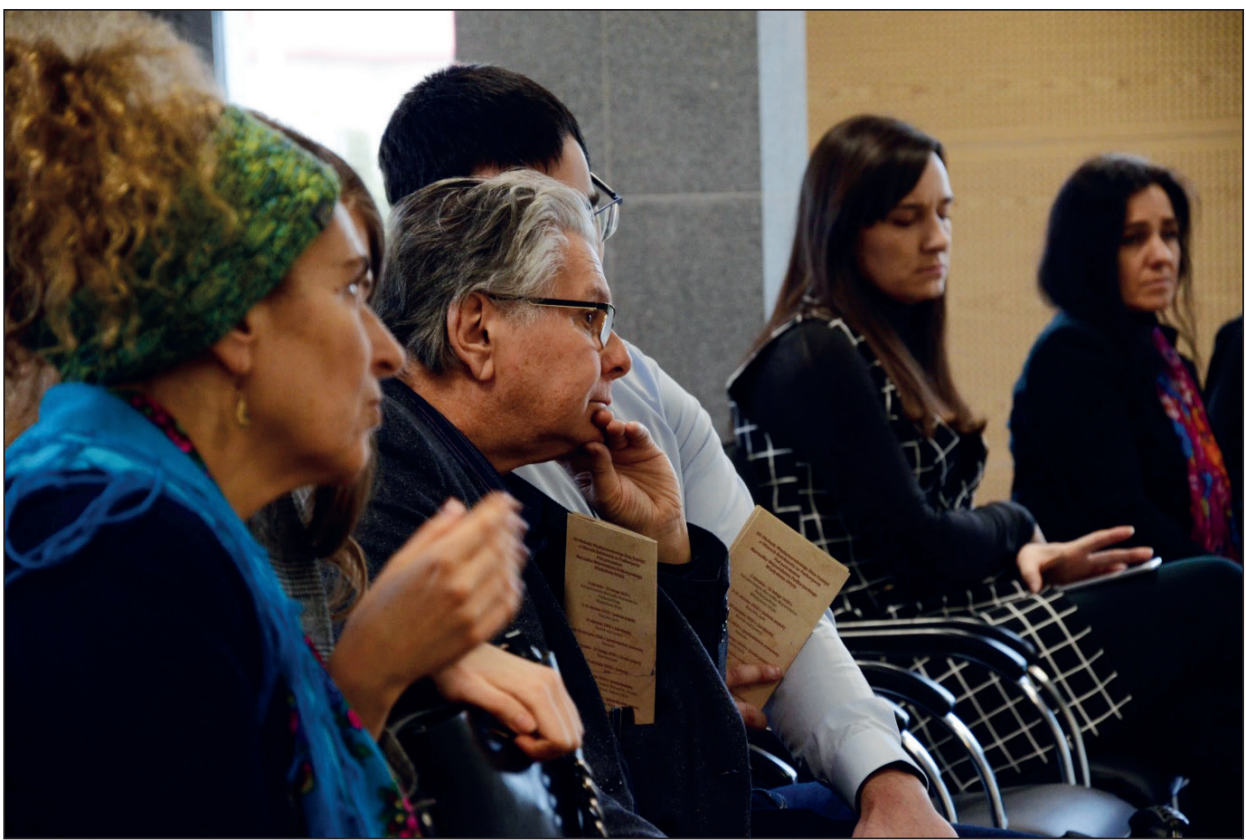

Fot. Maciej Zdun 


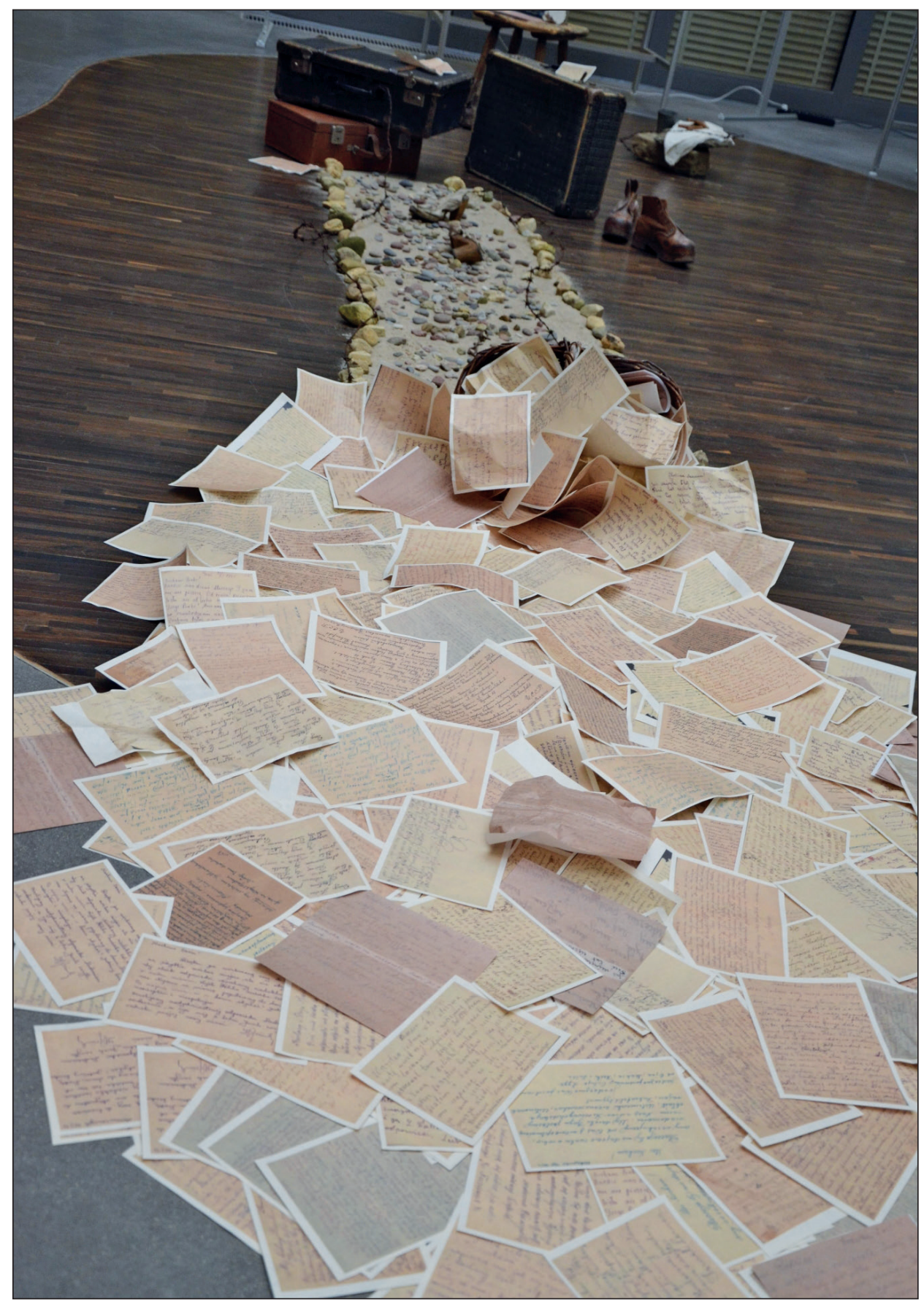

Fot. Maciej Zdun 


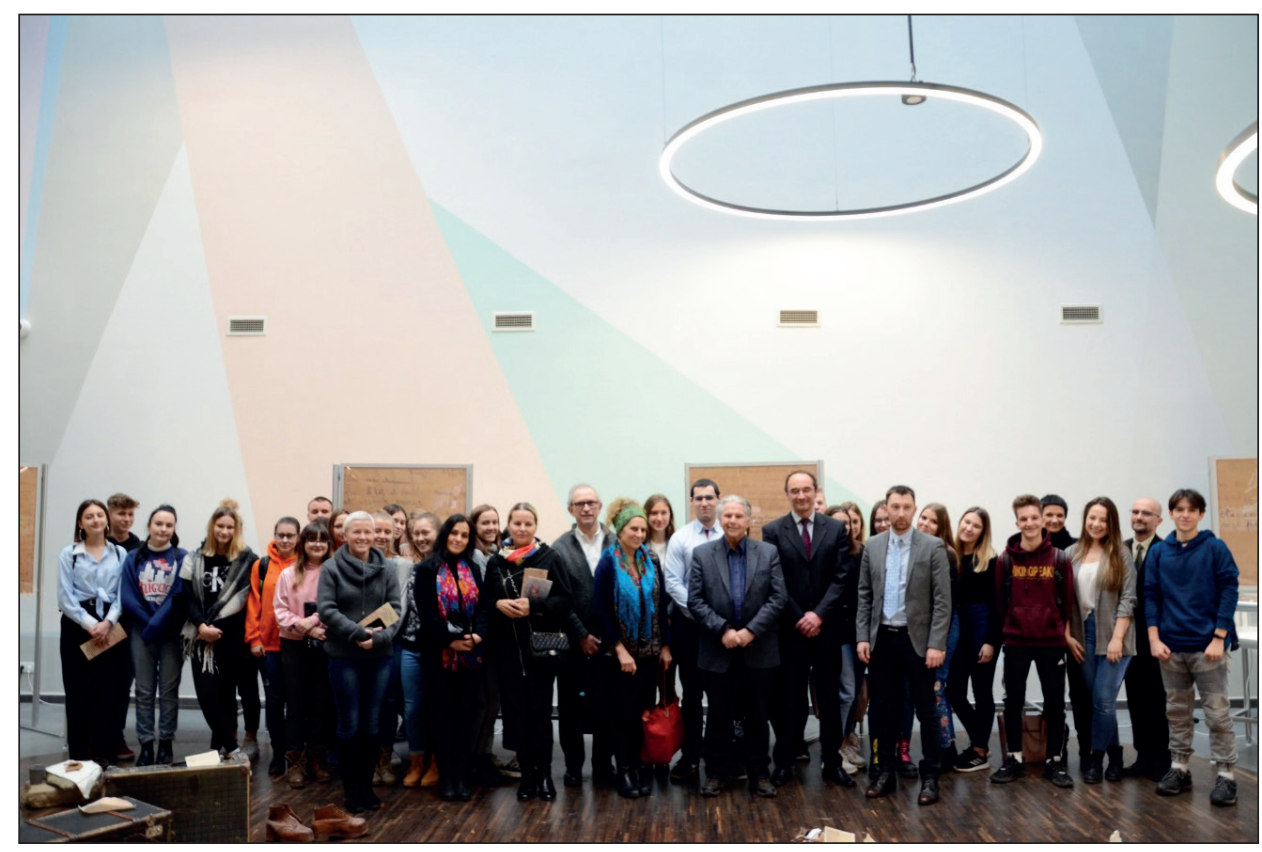

Fot. Maciej Zdun

Izabella Frużyńska

ORCID 0000-0002-7979-0775

DOI: $10.30657 /$ pha. 32.2020 .23

(Archiwum Państwowe w Rzeszowie) e-mail: IFruzynska@rzeszow.ap.gov.pl

Marek Gieroń

ORCID 0000-0002-5677-2646 DOI: $10.30657 /$ pha.32.2020.23

(Archiwum Państwowe w Rzeszowie) e-mail: MGieron@rzeszow.ap.gov.pl 